\title{
Monitoring and Exploring the Spatio-temporal Variation of Physico-chemical Variables of River Hadejia, Nigeria; Using Statistical Approach
}

\author{
Adam Babangida Maryam $^{1^{*}}$, Edegbene Augustine Ovie ${ }^{1}$ and Jibrin Gambo ${ }^{2}$ \\ ${ }^{1}$ Department of Biological Sciences, Faculty of Natural and Applied Sciences, Sule Lamido University, \\ Kafin Hausa, Nigeria. \\ ${ }^{2}$ Department of Foundation Courses and Remedial Studies, School of General Studies, \\ Binyaminu Usman Polytechnic, Nigeria.
}

Authors' contributions

This work was carried out in collaboration among all authors. Authors $A B M$ and EAO carried out the field and laboratory work and performed the statistical analyses. Authors ABM and JG designed the first draft of the manuscript. Author JG create study area map while author EAO supervised the entire work. All authors read and approved the final manuscript.

Article Information

DOI: $10.9734 / A J G R / 2020 / v 3 i 130100$ Editor(s):

(1) Dr. Xu Chong, Institute of Geology, China. Reviewers:

(1) Mbadu Zebe Victorine, Democratic Republic of the Congo. (2) Dorota Porowska, University of Warsaw, Poland.

(3) Qiong Shi BGI Marine, China. Complete Peer review History: http://www.sdiarticle4.com/review-history/54512

Original Research Article

Received 19 December 2019

Accepted 24 February 2020

Published 06 March 2020

\begin{abstract}
This study is aimed at assessing the ecological health condition of River Hadejia. The specific objectives are to; determine the monthly variation of the Physico-chemical parameters of River Hadejia. The physico-chemical analysis carried out on the water samples were: $\mathrm{pH}$, temperature, electrical conductivity, TDS, turbidity, nitrate, phosphate, DO, BOD, TRANSPARENCY, Depth and flow velocity and they were determined by standard APHA methods. The results of Physico-chemical parameters obtained were subjected to ANOVA using statistical package software, the mean electrical conductivity values range between $(104-127 \mu \mathrm{S} / \mathrm{cm})$. Nitrate in this study ranged from $0.04-0.80 \mathrm{mg} / \mathrm{l}$ and Station 3 had the highest nitrate value. The mean turbidity values obtained from the water samples of River Hadejia ranges from 124.56 $\pm 11.06-149.52 \pm 23.11$. Moreover, the temperature of Hadejia River varied from $13^{\circ} \mathrm{C}$ to $28^{\circ} \mathrm{C}$. The highest temperature
\end{abstract}


was in November at Station 1 while the lowest was recorded in February at station 1. The study was able to elucidate the effect of anthropogenic activities of the water quality of the River Hadejia.

Keywords: Variability; assessment; water-quality; river; statistics; Nigeria.

\section{INTRODUCTION}

Water Physico-chemical parameters variability in water bodies had both negative and positive effect on the functional and structural composition and diversity of aquatic biota [1]. Among the various water quality variables used in assessing ecological status of rivers, surface water temperature has a direct effect on the freshwater systems as it depicts the production rate of the system as has be reported by several authors [1,2] in some selected river in the Afrotropic. Other anthropogenic factors such as urbanisation and industrialization resulting in domestic and industrial wastewater discharges and changes in the natural and geological patterns as well as soils and hydrological alteration have a debilitating effect on water physico-chemistry of riverine systems [1,3]. Changes resulting from natural processes due to human activities can adversely affect ecosystem structure and function [1]. Water physicochemical has been used to assess the health of riverine systems for decades and has been used by aquatic resources managers in managing and sustaining the aquatic systems [3-5].

On the other hand, $\mathrm{pH}$ has also been used in complementation of other water physicochemical characteristics and it measures the concentration of hydrogen ions in the water [6]. Naturally occurring fresh waters have a $\mathrm{pH}$ range between 6.5 and 8.5 [2].The solubility and nutrient availability in water systems is determined by $\mathrm{pH}$ concentration $[7,8]$. Aside, $\mathrm{pH}$, another variable such as electrical conductivity conveys the degree of suspended solids in water systems $[9,10]$ and it is an indication of the amount of suspended solids which entails the flow of elctricity in the water body thereby favouring biota that may need electricity for the well being in the aquatic ecosystem.

Furthermore, Depth is another important factor in aquatic environment. The amount of oxygen varies with depth [2]. Increase in depth reduces dissolved oxygen availability in water system and also light penetration reduces with depth increase, this may be consequential to the survival rate of organisms that are benthic in nature [11]. This may cause such organisms to devise a survival mechanism as depth increases.

Other physico-chemical variables such as turbidity, TDS, DO, BOD and nutrients have their deferential roles in sharpening the structural and functional diversity of aquatic biota and reduction in a particular variable may either reduce or increase the concentration of other variables and this goes along way in sharpening the ecological state of riverine systems [12-20]. For instance the higher the DO concentration the lower the concentration of BOD.

Based on the varied importance of physicochemical variables in aquatic systems, and several studies have been conducted to determine their variation in freshwater systems $[2,1,12,13,17]$ this study was carried out to add to the growing pool of information with regard to monitoring of freshwater systems using physicochemical variables. Therefore, the aim of this study is to explore the spatio-temporal variation of physico-chemical variables in River Hadejia in a bid to monitor to ascertain the health staus of the river.

\section{MATERIALS AND METHODS}

\subsection{Study Area}

Hadejia River is located in Hadejia Local Government Area, Jigawa State, Nigeria, the River is located on Latitude $\left(12^{\circ} 13^{\prime}-13^{\circ} 60^{\prime} \mathrm{N}\right.$ and Longitude $9^{\circ} 22^{\prime}-11^{\circ} 00^{\prime} \mathrm{E}$ ). It is a tributary of the Lake Chad [21]. The Hadejia River splits into three channels in the Hadejia-Nguru Wetland (HNW): the Marma Channel which flows into Nguru Lake, the Old Hadejia River which joins up with the Jama'are River to become the Yobe River and the relatively small Burum Gana River. The total annual rainfall of Hadejia area is about $600 \mathrm{~mm}$ [22]. Most of the flow in the Hadejia River system is controlled by Tiga Dam and Challawa Dam [23,24].

\subsection{Sampling Stations}

For this study, three (3) well marked stations were selected based on their distant and level of anthropogenic activities. The three stations were; 
- Station one (1) Aguyaka (Latitude $12.439020^{\circ} \mathrm{N}$ and longitude $10.076621^{\circ} \mathrm{E}$ ), characterized by human activities such as bathing, farming, fishing and transportation.

- Station two (2) BakinGada (Latitude $12.440571^{\circ} \mathrm{N}$ and longitude $\left.10.031040 \mathrm{E}\right)$, also been disturbed with human activities.

- Station three (3) MahucinSarki (Latitude $12.437004^{\circ} \mathrm{N}$ and longitude $10.041218^{\circ} \mathrm{E}$ ), was characterized by activities such as open defacations, bathing, washing, heavy farming activity along the river bank.

\subsection{Physico-chemical Analysis}

The physicochemical analysis carried out on the water samples included the $\mathrm{pH}$, temperature,
Electrical Conductivity, Total Dissolved Solids (TDS), Turbidity, Nitrate, Phosphate, Dissolved Oxygen (DO), Biochemical Oxygen Demand (BOD), Transparency, Depth and flow velocity which were determined by standard methods [25]. The Transparency, depth, temperature and Flow velocity were determined and recorded immediately at the site. Water temperature measured insitu using mercury-in-glass thermometer $\left({ }^{\circ} \mathrm{C}\right), \mathrm{pH}$ was determine using a $\mathrm{pH}$ meter. Water depth was measured using a calibrated stick in meter. Turbidity meter was used in measuring turbidity (NTU) while electrical conductivity was measured using conductivity meter $(\mu \mathrm{S} / \mathrm{cm})$. Transparency and flow velocity were measured using seechi disc (metre) and a timed weighted cork (m/s) respectively. Dissolved oxygen, BOD, phosphate and nitrate were determined according [25] methods.

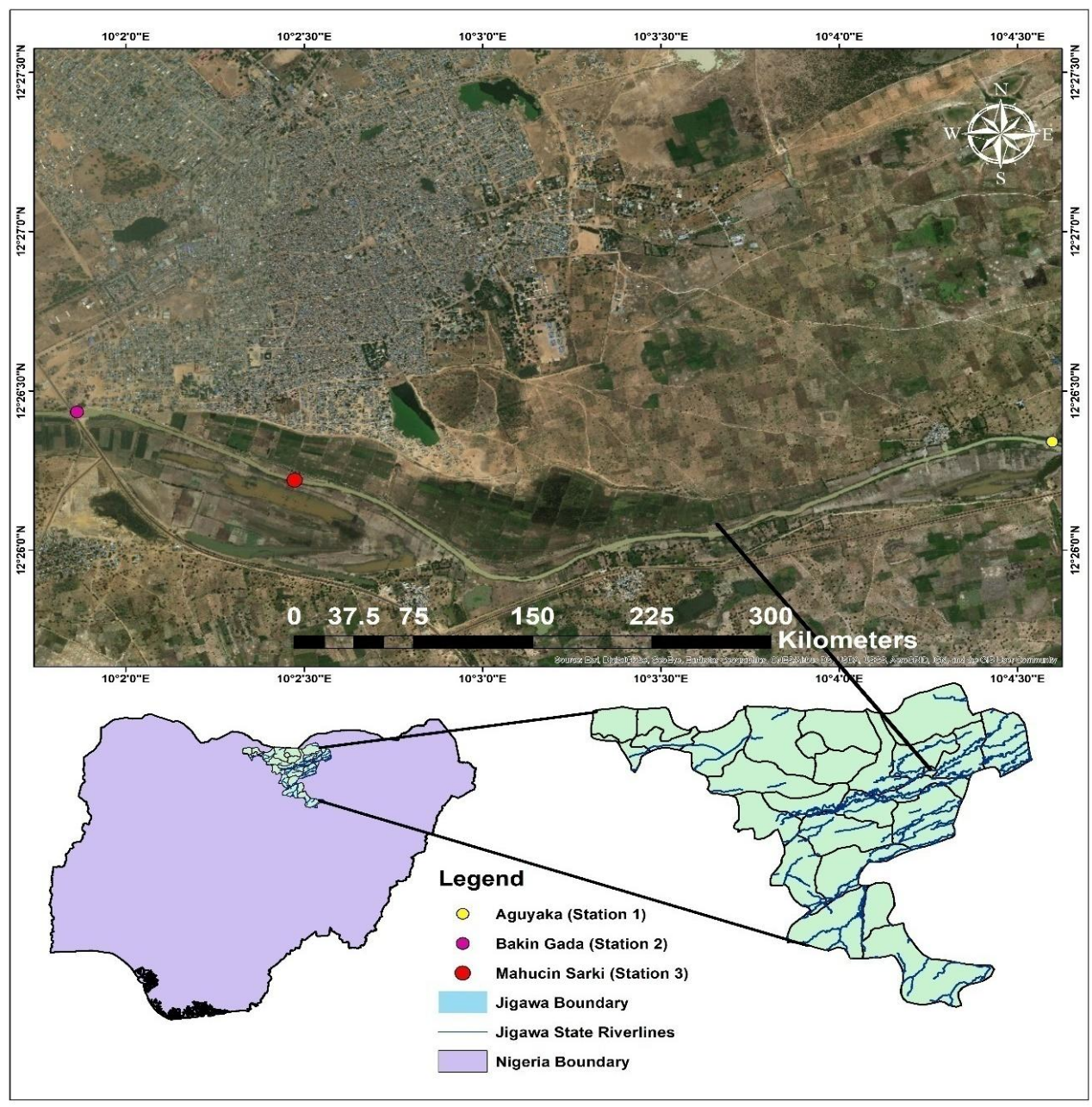

Fig. 1. Map of the study area showing the River Hadejia and sample stations 


\subsection{Data Analyses}

The mean and standard deviation for each physico-chemical variables were calculated per station using PAST statistical package [26]. One way analysis of variance (ANOVA) was used to obtain the differences between sampling stations and months at probability level of 0.05 . Microsoft Excel was used to draw all the graphs of physico-chemical variables monthly variation. performed using PAST statistical package [26].

\section{RESULTS AND DISCUSSION}

Dissolved Oxygen (DO) levels of 0.25 to 6.39 $\mathrm{mg} / \mathrm{L}$ in this study were similar to $1.20 \mathrm{mg} / \mathrm{L}$ to $9.40 \mathrm{mg} / \mathrm{L}$ reported by Edokpayi et al. [27] in Ibiekuma River and Ibuya River in Old national park, Sepeteri. The lowest value was observed in Station 1 in November and the highest was also recorded in Station 1 in the month March. The decrease in DO value observed at some points may be due to discharge of organic wastes at such periods, which may led to biological respiration and decomposition processes, which in turn reduced the concentration of DO in water bodies. This is in consonance with the findings of [7] who reported that water with high organic or inorganic pollution may contain very little oxygen in them.

Biological oxygen demand (BOD) values indicate the level of organic pollution in water quality [28]. In this study the values of BOD range between $7.08 \mathrm{mg} / \mathrm{L}-4.19 \mathrm{mg} / \mathrm{L}$. According to several authors $[13,28]$, classified using $B O D$ of river as follows: unpolluted (BOD<1.0 mg/l), moderately polluted (BOD between 2-9 $\mathrm{mg} / \mathrm{l}$ ) and heavily polluted $(B O D>10.0 \mathrm{mg} / \mathrm{l}$ i.e. it indicates that organic matter increases bacteria decomposition. From this classification, it can be interpreted that the Hadejia River is moderately polluted.

The conductivity of water is useful and accessible indicator of water salinity or total salt content [28]. From this present study, the mean conductivity values range between (104-127 $\mu \mathrm{S} / \mathrm{cm})$ which is a reflection of the amount of dissolved ions in the river. This result is in contrast with a similar report by several authors $[2,29]$ in Warri River, Delta State, Nigeria. They recorded a conductivity value of 45.5 - 1735 $\mu \mathrm{S} / \mathrm{cm}$ which showed that the river is heavily polluted. Similarly, in other part of Africa, [30] reported a conductivity value range of 105 $1200 \mu \mathrm{S} / \mathrm{cm}$ which is in consonant with this present study in Hadejia River.
Nitrate and phosphate are indicators of organic pollution [30]. Their main source in a river system is through organic residue of plants and animals and sewage fertilizer. Nitrate concentration is associated with algae growth and eutrophication. Nitrate in this present study ranged from $0.04-$ $0.80 \mathrm{mg} / \mathrm{l}$ and Station 3 had the highest nitrate value probably due to increased farming activities around the station. This range recorded compares favourably with similar investigation carried out by Oluyemi et al. [29] in Orogodo River, Delta State. Phosphate value recorded in this study conforms favourably with similar research by Arimoro et al. [2] in Orogodo River, Delta State.

The mean turbidity values obtained from the water samples of River Hadejia ranges from 124.56 $\pm 11.06-149.52 \pm 23.11$. Water turbidity is very important because high turbidity is often associated with higher level of disease-causing microorganisms such as bacteria and other parasites [31].

\subsection{Physicochemical Characteristics}

Sampling stations and physico-chemical variables variation are shown in Table 1 . All the physicochemical parameters used in this study shows no significance difference among sampling stations $(P>0.05)$, while between the months $\mathrm{pH}$, Biological Oxygen Demand, Nitrates, Air Temperature, Total Dissolved Solids, Depth, Electrical Conductivity, and Transparency shows significant difference among sampling month $(\mathrm{P}<0.05)$ and Phosphate, Turbidity, Flow velocity, Dissolved Oxygen, and Water Temperature shows no significance differences among sampling month $(P>0.05)$. However, Water Temperature, Phosphate, Flow velocity, Dissolved Oxygen and Turbidity shows no significant difference among both sampling months and stations $(\mathrm{P}>0.05)$. There are significance differences between the $\mathrm{pH}$, Biological Oxygen Demand, Nitrates, Air Temperature, Total Dissolved Solids, Depth, Electrical Conductivity, and Transparency among sampling months $(\mathrm{P}<0.05)$, but shows no significance difference among sampling stations $(P>0.05)$. The mean surface water temperature values among the sampling stations show that there are no significant differences between all the stations. Significant difference was observed among the sampling months with mean surface water Temperature values of $22.67^{\circ} \mathrm{C}, 20.00^{\circ} \mathrm{C}$, $19.67^{\circ} \mathrm{C}, 14.33^{\circ} \mathrm{C}$ and $14.33^{\circ} \mathrm{C}$ in November, December, January, February, and March 
respectively. Air temperature shows no significant difference among all the sampling stations and months at $95 \%$ level of significance $(\mathrm{P}<0.05)$. The mean value of water $\mathrm{pH}$ in station 1 , station 2 and station 3 , were not found to vary significantly that is there is no significant differences between them. There is no significant difference in $\mathrm{pH}$ among the sampling months of November, December, January, February and March. The mean value of Total Dissolved Solids shows no significant difference at $95 \%$ level of significant in all the stations $(P>0.05)$. There was significant difference in TDS observed among all the study months at $95 \%$ level of significance. There was no significant difference in DO between all the sampling stations and the Months at $95 \%$ level of significant. Statistically no significant difference was observed in BOD between the stations 1,2 and 3 at 95\% level of significance while between the Months significant variation was observed in BOD as presented as well as there is no significant variation in Phosphate between the all the stations and months at $95 \%$ level of significance. Also no significant difference was observed in Nitrate among all sampling stations, there was significant variation in Nitrate between the Months at $95 \%$ level of significance. There was no significant difference in the mean values of Depth observed among all the sampling stations at $95 \%$ level of significance. Between the months there was significant different observed at $95 \%$ level of significance. Statistically no significant difference was observed in transparency among all the stations at $95 \%$ level of significance. Also among the months, there was significant difference observed, at $95 \%$ level of significance. There was no significant difference in the mean values of Flow velocity observed among all the sampling stations and the Months at $95 \%$ level of significance as all indicated in Table 1.

\subsection{Spatio-temporal Variation Physicochemical Parameters Hadejia River}

\subsubsection{Water temperature}

The mean surface water temperature among the stations ranged from $18.60^{\circ} \mathrm{C}, 18.00^{\circ} \mathrm{C}$ and $18.00^{\circ} \mathrm{C}$ in station 2,3 and 1 respectively. Station 2 had the highest mean value of $18.60^{\circ} \mathrm{C}$ followed by station 3 and station 1 which has the lowest mean value. In the month of November there is an increase in the mean values of surface water temperature but, decreases during the month of January and February as shown in Fig. 2.

\subsubsection{Air temperature}

The mean values of air temperature ranged from $23.80^{\circ} \mathrm{C}, 23.60^{\circ} \mathrm{C}$ and $21.00^{\circ} \mathrm{C}$ in station 1,3 and station 2 respectively. The highest mean value of Air temperature was observed in station 1 followed by station 3 and then station 2 . The highest air temperature mean value was observed in the month of January and the lowest mean value of air temperature was observed in the month of February as shown in Fig. 3.

\subsubsection{Water $\mathrm{pH}$}

The measure of hydrogen ion concentration $(\mathrm{pH})$ mean values of River Hadejia ranged from 8.18 in station 1, 7.64 in station 2 and 7.48 in station 3 . There is an increase in $\mathrm{pH}$ values during the month February, but the mean values of $\mathrm{pH}$ decreases during the month of November as shown in Fig. 4.

\subsubsection{Total Dissolved Solid (TDS)}

The concentration of total dissolved solids of River Hadejia during the period of study was found to range from $69.02 \mathrm{mg} / \mathrm{L}, 67.92 \mathrm{mg} / \mathrm{L}$ and $64.46 \mathrm{mg} / \mathrm{L}$ in station 3, 2 and 1 respectively. The highest mean value was observed in stations 2 and 3 in December followed then station 1 in November, also there was fluctuations in Total Dissolved Solids values during the month of November, December, January, February and March in station 3, as shown in Fig. 5.

\subsubsection{Dissolved Oxygen (DO)}

The mean surface values of $D O$ ranged from $3.00 \mathrm{mg} / \mathrm{L}, 2.12 \mathrm{mg} / \mathrm{L}$, and $1.99 \mathrm{mg} / \mathrm{L}$ in stations of in

\begin{abstract}
November then station 2 in March as shown in
\end{abstract}
Fig. 7. 
Table 1. Mean values of physicochemical parameter of the study stations of Hadejia River (from November 2018 to March 2019)

\begin{tabular}{|c|c|c|c|c|c|c|c|}
\hline \multirow[t]{2}{*}{ Parameters } & \multirow[t]{2}{*}{ Station 1} & \multirow[t]{2}{*}{ Station 2} & \multirow[t]{2}{*}{ Station 3} & \multicolumn{2}{|c|}{ Months } & \multicolumn{2}{|c|}{ Stations } \\
\hline & & & & $\begin{array}{l}\text { F- } \\
\text { value }\end{array}$ & $\begin{array}{l}\text { P- } \\
\text { value }\end{array}$ & $\begin{array}{l}\text { F- } \\
\text { value }\end{array}$ & $\begin{array}{l}P \text { - } \\
\text { value }\end{array}$ \\
\hline $\begin{array}{l}\text { Water Temperature } \\
\left({ }^{\circ} \mathrm{C}\right)\end{array}$ & $\begin{array}{l}18.00 \pm 4.30 \\
(13.00-23.00)\end{array}$ & $\begin{array}{l}18.60 \pm 2.96 \\
(15-22.00)\end{array}$ & $\begin{array}{l}18.00 \pm 3.94 \\
(14.00-23.00)\end{array}$ & 40.77 & 0.01 & 0.04 & 0.96 \\
\hline Air Temperature $\left({ }^{\circ} \mathrm{C}\right)$ & $\begin{array}{l}23.80 \pm 3.63 \\
(20.00-28.00)\end{array}$ & $\begin{array}{l}21.00 \pm 2.35 \\
(19.00-25.00)\end{array}$ & $\begin{array}{l}23.60 \pm 2.88 \\
(20.00-26.00)\end{array}$ & 4.91 & 0.02 & 1.36 & 0.29 \\
\hline$\overline{\mathrm{pH}}$ & $\begin{array}{l}8.18 \pm 0.59 \\
(7.4-9.0)\end{array}$ & $\begin{array}{l}7.64 \pm 0.94 \\
(6 . .2-8.7)\end{array}$ & $\begin{array}{l}7.48 \pm 0.37 \\
(7.1-8.1)\end{array}$ & 5.13 & 0.02 & 1.47 & 0.27 \\
\hline Transparency $(\mathrm{cm})$ & $\begin{array}{l}11.45 \pm 8.26 \\
(1.85-19.00)\end{array}$ & $\begin{array}{l}12.99 \pm 11.48 \\
(1.30-29.00)\end{array}$ & $\begin{array}{l}11.74 \pm 8.44 \\
(1.25-20.00)\end{array}$ & 37.89 & 0.00 & 0.04 & 0.96 \\
\hline Depth (m) & $\begin{array}{l}1.03 \pm 0.16 \\
(0.89-1.30)\end{array}$ & $\begin{array}{l}0.81 \pm 0.25 \\
(0.59-1.23)\end{array}$ & $\begin{array}{l}1.05 \pm 0.13 \\
(0.91-1.25)\end{array}$ & 4.24 & 0.03 & 2.55 & 0.12 \\
\hline $\begin{array}{l}\text { Dissolved Oxygen } \\
\text { (DO) (mg/L) }\end{array}$ & $\begin{array}{l}3.00 \pm 2.41 \\
(0.46-5.93) \\
\end{array}$ & $\begin{array}{l}1.99 \pm 2.00 \\
(0.30-5.21) \\
\end{array}$ & $\begin{array}{l}2.12 \pm 2.63 \\
(0.25-6.39) \\
\end{array}$ & 3.00 & 0.07 & 0.27 & 0.77 \\
\hline $\begin{array}{l}\text { Biological Oxygen } \\
\text { Demand BOD (mg/L) }\end{array}$ & $\begin{array}{l}0.29 \pm 4.39 \\
(-7.08-3.68)\end{array}$ & $\begin{array}{l}-0.21 \pm 4.08 \\
(-6.85-3.95) \\
\end{array}$ & $\begin{array}{l}-0.62 \pm 3.86 \\
(-6.49-4.19) \\
\end{array}$ & 60.99 & 0.00 & 0.66 & 0.94 \\
\hline $\begin{array}{l}\text { Total Dissolved } \\
\text { Solids (TDS) (mg/L) }\end{array}$ & $\begin{array}{l}64.46 \pm 5.36 \\
(57.80-70.70)\end{array}$ & $\begin{array}{l}67.92 \pm 5.80 \\
(63.40-76.60)\end{array}$ & $\begin{array}{l}69.02 \pm 5.04 \\
(64.70-77.30) \\
\end{array}$ & 4.17 & 0.03 & 0.97 & 0.41 \\
\hline Nitrate (mg/L) & $\begin{array}{l}0.46 \pm 0.26 \\
(0.14-0.73)\end{array}$ & $\begin{array}{l}0.55 \pm 0.25 \\
(0.26-0.75)\end{array}$ & $\begin{array}{l}0.46 \pm 0.33 \\
(0.04-0.80)\end{array}$ & 5.59 & 0.01 & 0.18 & 0.84 \\
\hline Phosphate (mg/L) & $\begin{array}{l}0.77 \pm 0.29 \\
(0.25-0.97)\end{array}$ & $\begin{array}{l}0.88 \pm 0.12 \\
(0.72-1.00)\end{array}$ & $\begin{array}{l}0.77 \pm 0.38 \\
(0.12-1.10)\end{array}$ & 3.04 & 0.07 & 0.28 & 0.76 \\
\hline $\begin{array}{l}\text { Electrical } \\
\text { Conductivity }(\mu \mathrm{S} / \mathrm{cm})\end{array}$ & $\begin{array}{l}114.20 \pm 6.66 \\
(108.40-125.40)\end{array}$ & $\begin{array}{l}112.66 \pm 7.31 \\
(105.50-124.80)\end{array}$ & $\begin{array}{l}113.86 \pm 8.56 \\
(104.00-127.00)\end{array}$ & 12.16 & 0.00 & 0.06 & 0.94 \\
\hline Flow Velocity $\left(\mathrm{ms}^{-1}\right)$ & $\begin{array}{l}0.21 \pm 0.16 \\
(0.12-0.49)\end{array}$ & $\begin{array}{l}0.25 \pm 0.12 \\
(0.13-0.46)\end{array}$ & $\begin{array}{l}0.26 \pm 0.09 \\
(0.13-0.35)\end{array}$ & 2.29 & 0.13 & 0.24 & 0.79 \\
\hline$\overline{\text { Turbidity (NTU) }}$ & $\begin{array}{l}149.52 \pm 23.11 \\
(124-179.3)\end{array}$ & $\begin{array}{l}124.56 \pm 11.06 \\
(111.6-139)\end{array}$ & $\begin{array}{l}124.98 \pm 18.28 \\
(102-147)\end{array}$ & 2.09 & 0.16 & 3.09 & 0.08 \\
\hline
\end{tabular}

Note: Values are means+ standard deviation, Maximum and minimum values in parenthesis

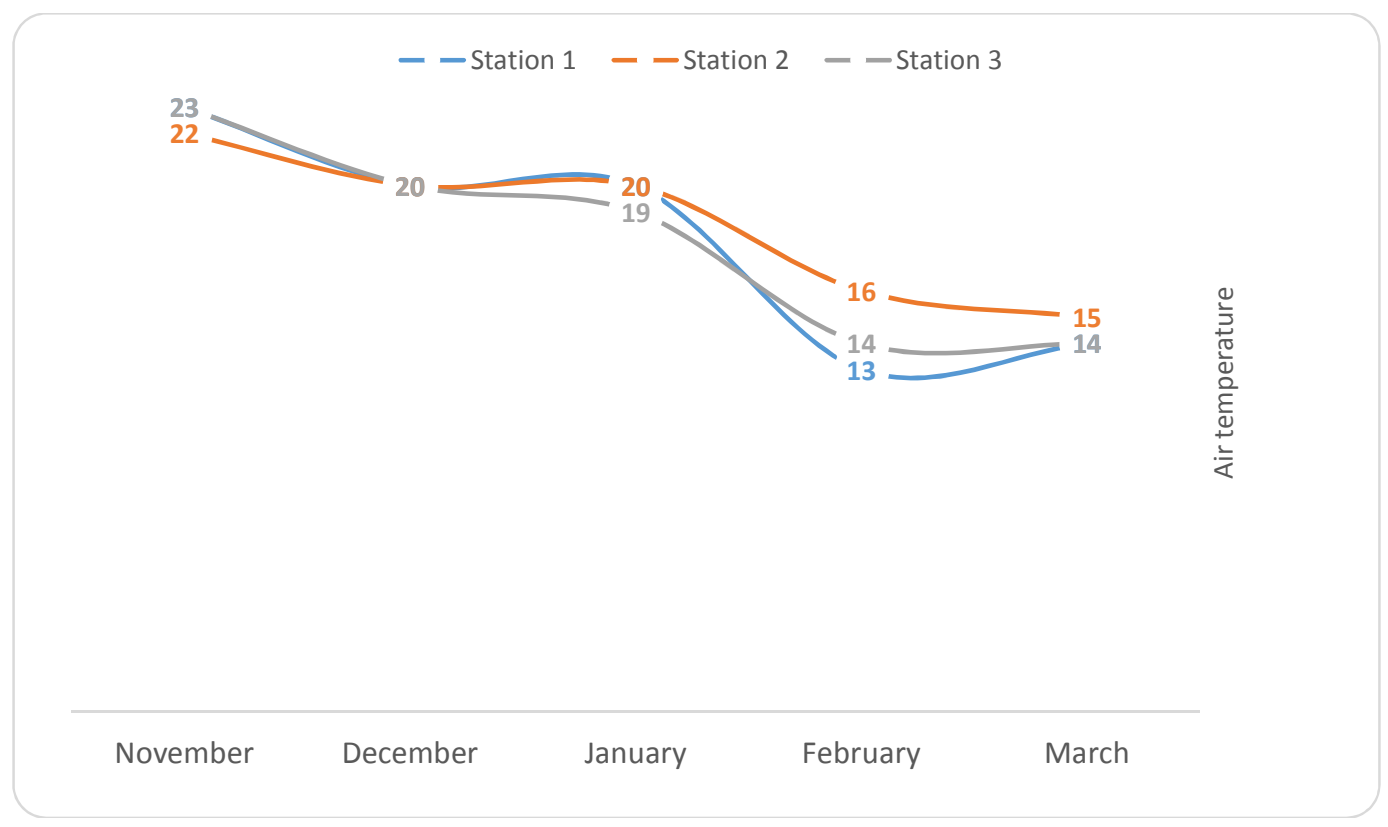

Fig. 2. Water temperature variations among three sampling stations of River Hadejia 


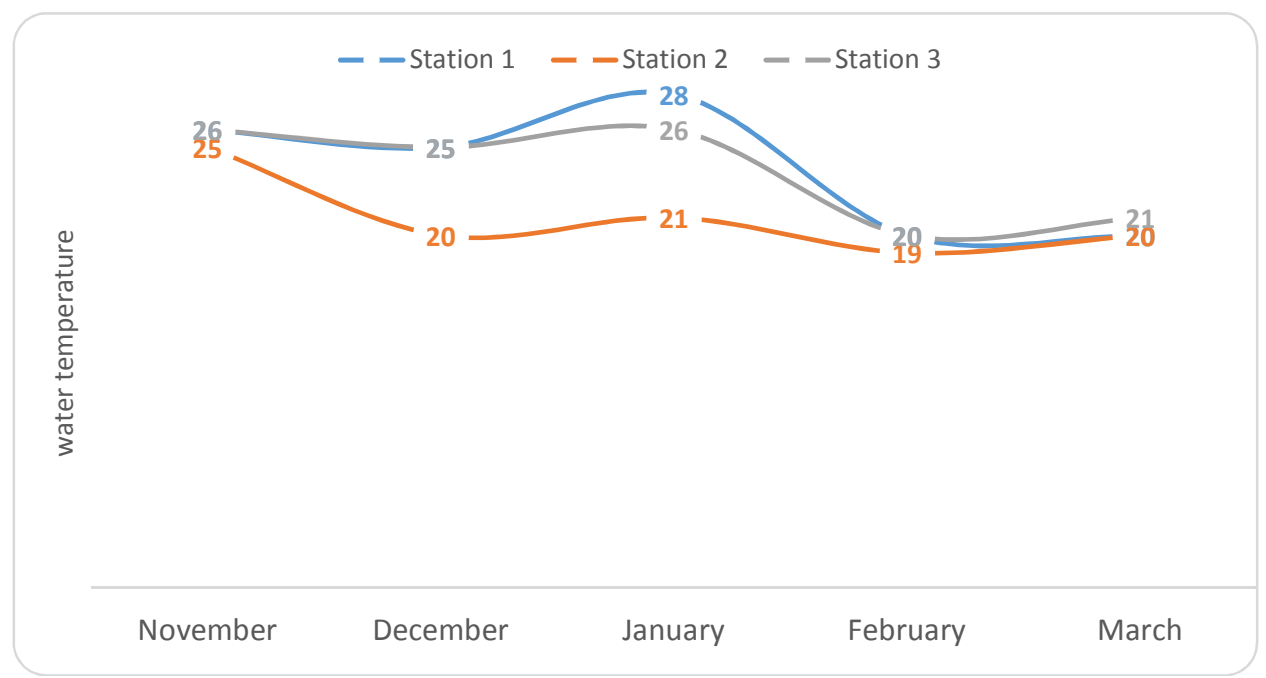

Fig. 3. Air temperature variations among three sampling stations of River Hadejia

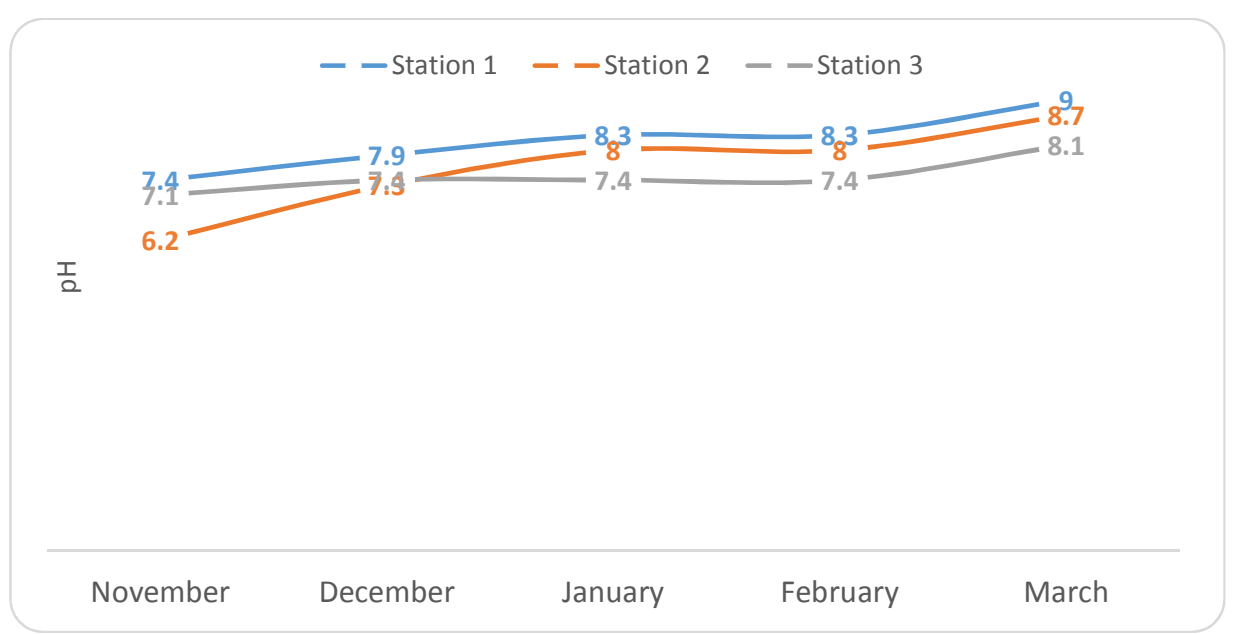

Fig. 4. pH variations among three sampling stations of River Hadejia

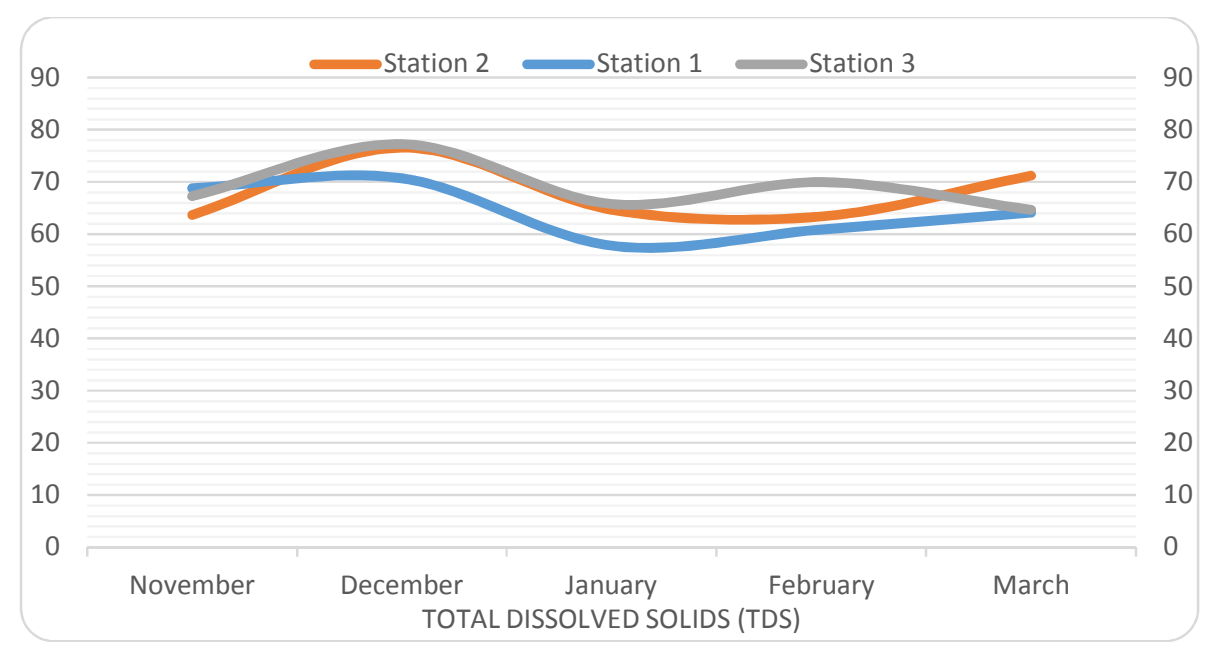

Fig. 5. Total dissolved solutes variations among three sampling stations of River Hadejia 


\subsubsection{Phosphate}

The mean values of Phosphate in River Hadejia ranged from $0.88 \mathrm{mg} / \mathrm{L}, 0.77 \mathrm{mg} / \mathrm{L}$ and $0.77 \mathrm{mg} / \mathrm{L}$ in stations 1,2 and 3 respectively. Station 3 in February had the highest Phosphate value followed by station 2 in November and then station 1 in March. There was a drop in Phosphate in stations 1 and 3 in November as shown in Fig. 8.

\subsubsection{Nitrate}

Nitrate concentration of River Hadejia ranged from $0.55 \mathrm{mg} / \mathrm{L}$ in station $2,0.46 \mathrm{mg} / \mathrm{L}$ in station 1 and $0.46 \mathrm{mg} / \mathrm{L}$ in station 3, as shown in Fig. 8, stations 1 and 3 has the same mean values of $0.46 \mathrm{mg} / \mathrm{L}$. The highest mean value was observed in station 3 in February and March followed by station 2 in November and 3 March as shown in Fig. 9.

\subsubsection{Depth}

The mean value of Depth in Hadejia River during the period of study was found to range from 1.05 $\mathrm{m}, 1.03 \mathrm{~m}$, and $0.81 \mathrm{~m}$ in station 3,1 and 2 respectively. The highest value observed in station 1 in November, followed by stations 2 and 3 in November while station 2 in February had the lowest value of depth value as shown in Fig. 10.

\subsubsection{Transparency}

The mean values of transparency in River Hadejia ranged from $12.99 \mathrm{~cm}, 11.74 \mathrm{~cm}$ and $11.45 \mathrm{~cm}$ in station 2, 3 and 1 respectively. Station 2 in November had the highest mean transparency value fallowed by station 2 in
November then stations 1 and 2 also in November and the lowest was observed in stations 1, 2 and 3 in January. There was an increase in transparency mean value in November as shown in Fig. 11.

\subsubsection{Flow velocity}

The mean values of Flow velocity ranged from $0.26 \mathrm{~ms}^{-1}, 0.25 \mathrm{~ms}^{-1}$ and $0.21 \mathrm{~ms}^{-1}$ in stations 3,2 and station 1 respectively. The highest Flow Velocity value was observed in the month of December in station 1, then followed by in January in station 2 as shown in Fig. 12.

\subsubsection{Electrical conductivity}

The mean values of Electrical conductivity ranged from $114.20 \pm 6.66 \mu \mathrm{S} / \mathrm{cm}^{-1}$ in station 1, $113.86 \pm 8.56 \mu \mathrm{S} / \mathrm{cm}^{-1}$ in station 3 and $112.66 \pm 7.31 \mu \mathrm{S} / \mathrm{cm}^{-1}$ in station 2. The highest Electrical conductivity value was recorded in December $\left(127 \mu \mathrm{S} / \mathrm{cm}^{-1}\right)$ in station 3, followed by station 1 also in December and then lowest value was recorded in February $\left(104 \mu \mathrm{S} / \mathrm{cm}^{-1}\right)$ in station 3 as shown in Fig. 13.

\subsubsection{Turbidity (NTU)}

The mean values of Turbidity ranged from $149.52 \pm 23.11$ NTU in station 1 , $124.98 \pm 18.28 \mathrm{NTU}$ in station 3 and $124.56 \pm 11.06 \mathrm{NTU}$ in station 2. The highest Turbidity was recorded in December (179.3NTU) in station 1 then followed by 147NTU in station 3 in January and the lowest was recorded in November (102NTU) in station 3 as shown in Fig. 14.

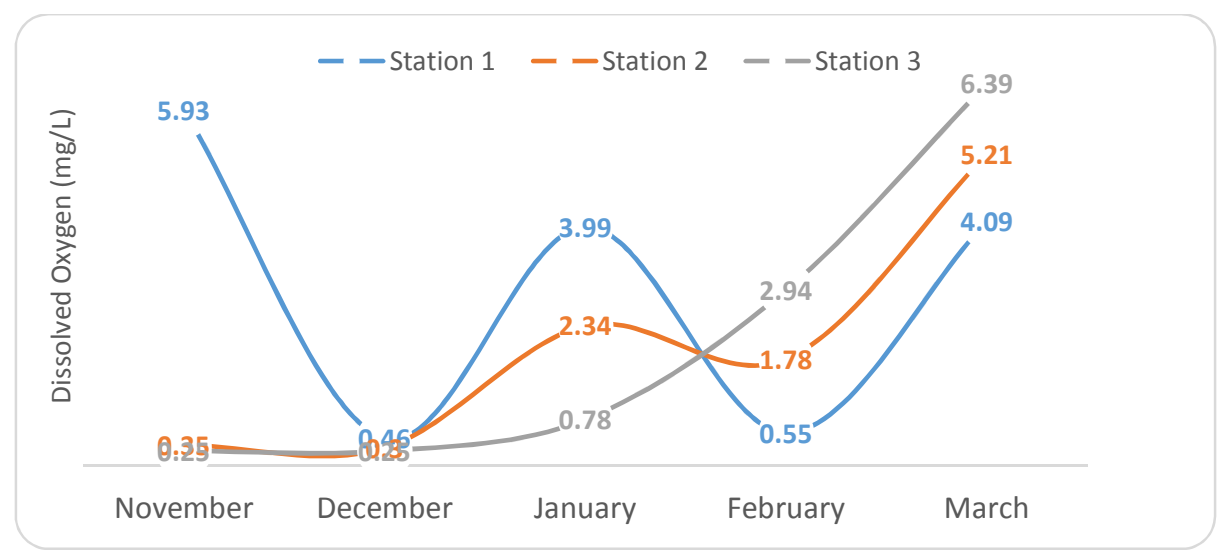

Fig. 6. Dissolved oxygen variations among three sampling stations of River Hadejia 


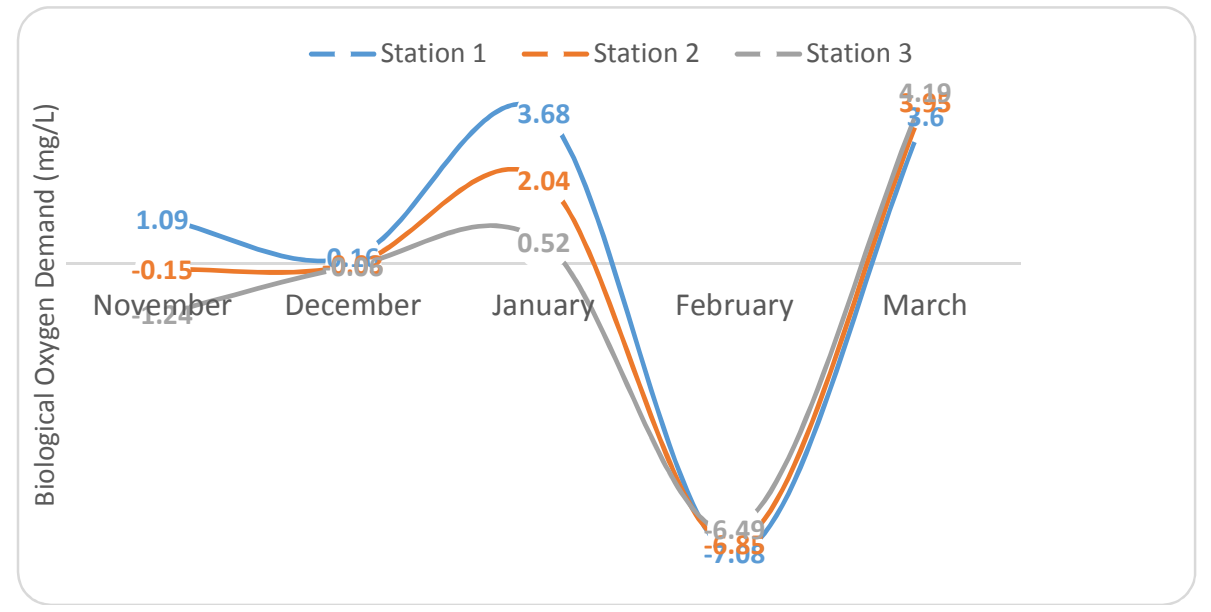

Fig. 7. Biological oxygen demand variations among three sampling stations of River Hadejia

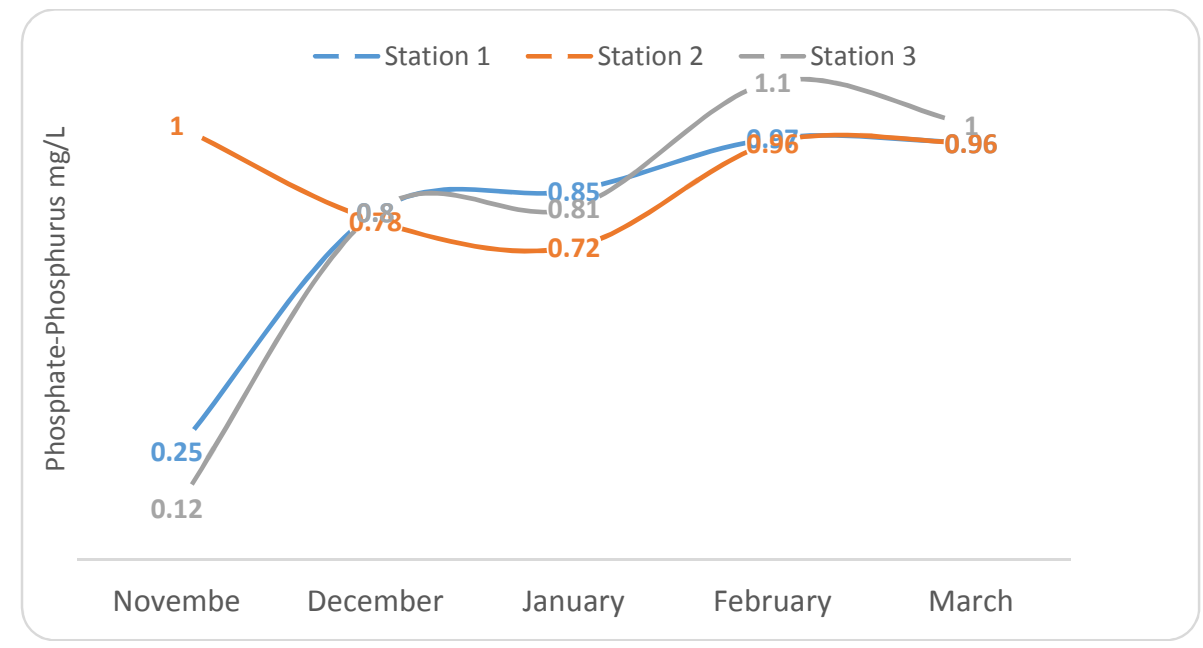

Fig. 8. Phosphate variations among three sampling stations of River Hadejia

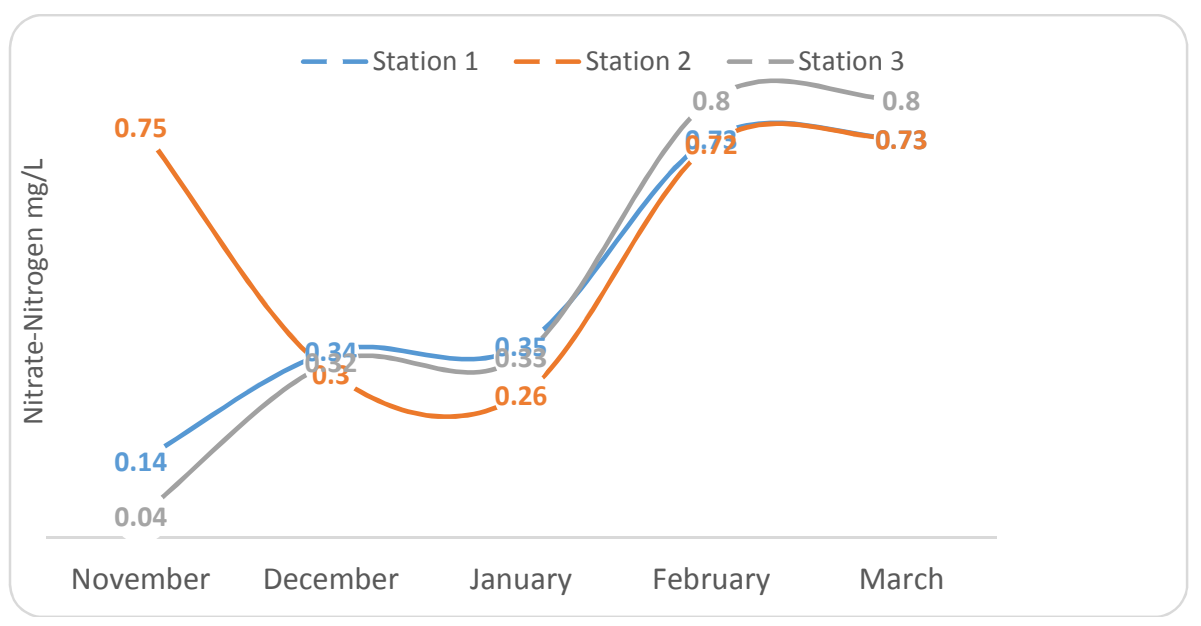

Fig. 9. Nitrate variations among three sampling stations of River Hadejia 


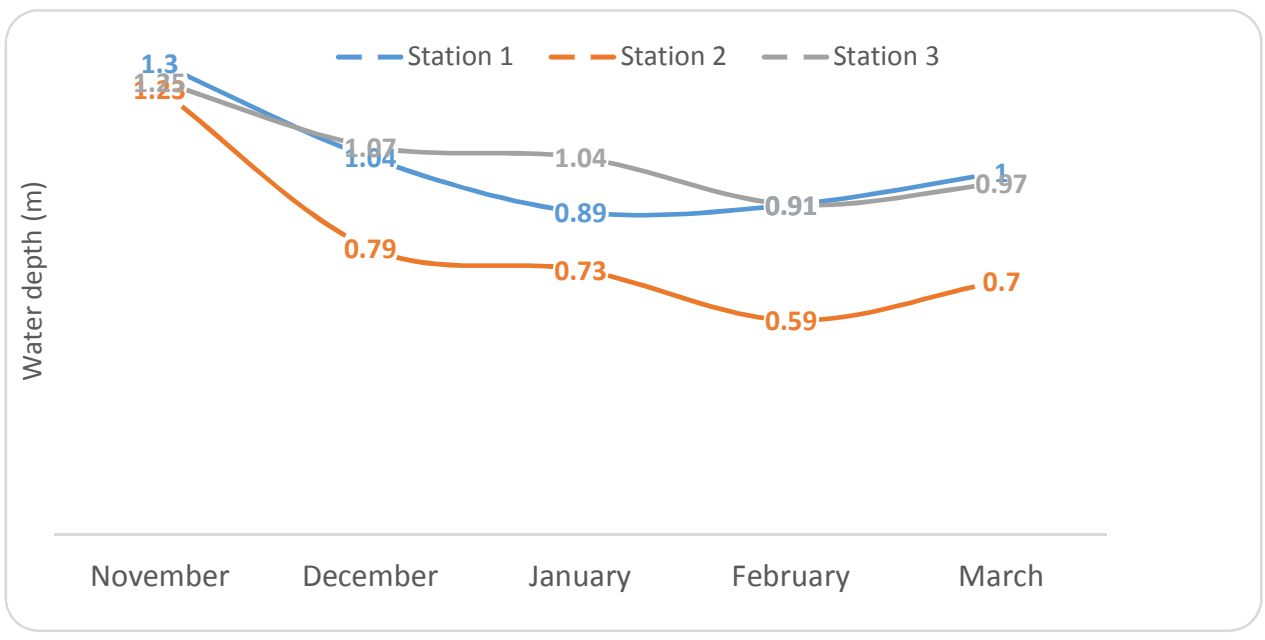

Fig. 10. Water depth variations among three sampling stations of River Hadejia

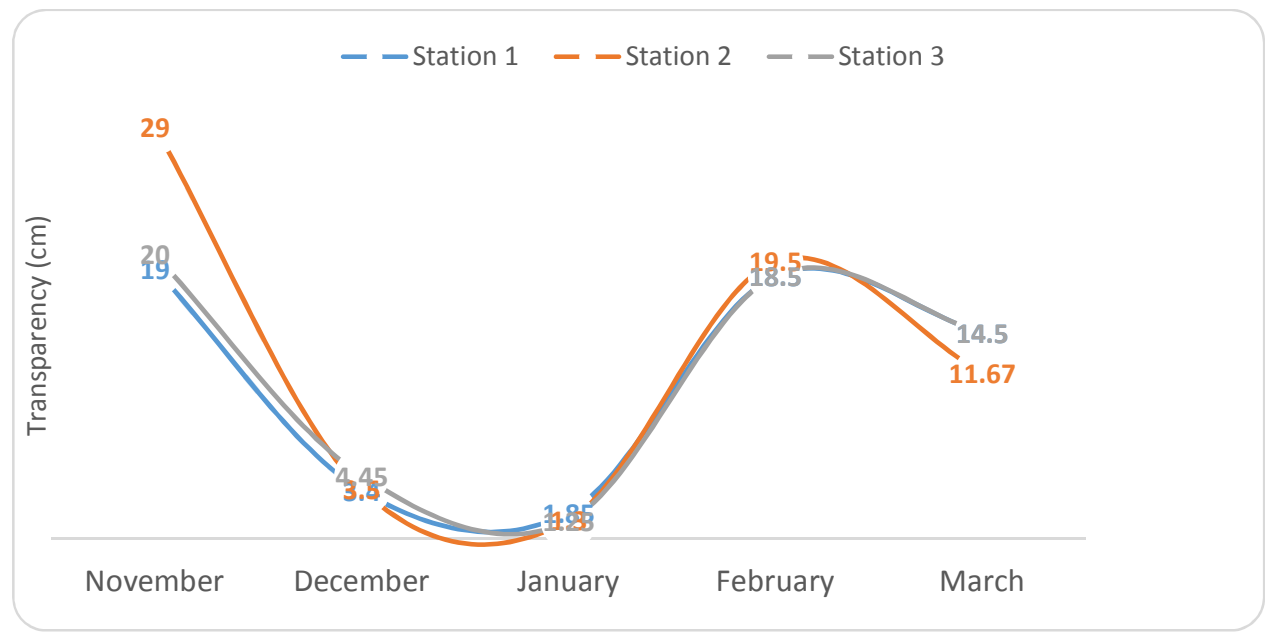

Fig. 11. Transparency variations among three sampling stations of River Hadejia

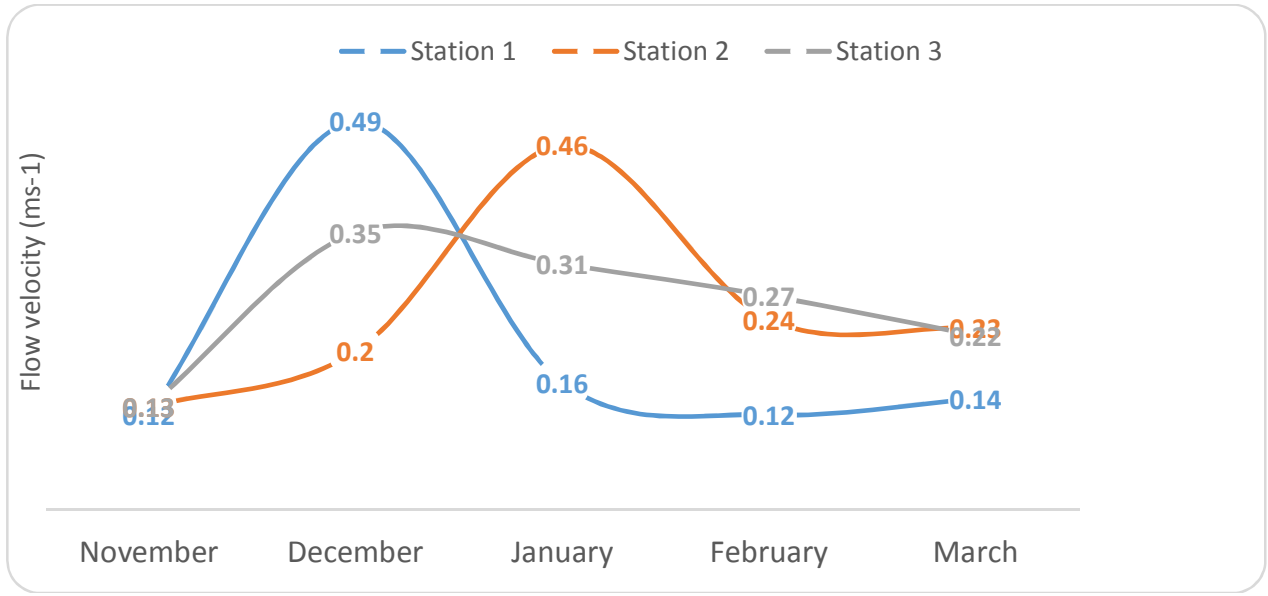

Fig. 12. Flow velocity variations among three sampling stations of River Hadejia 


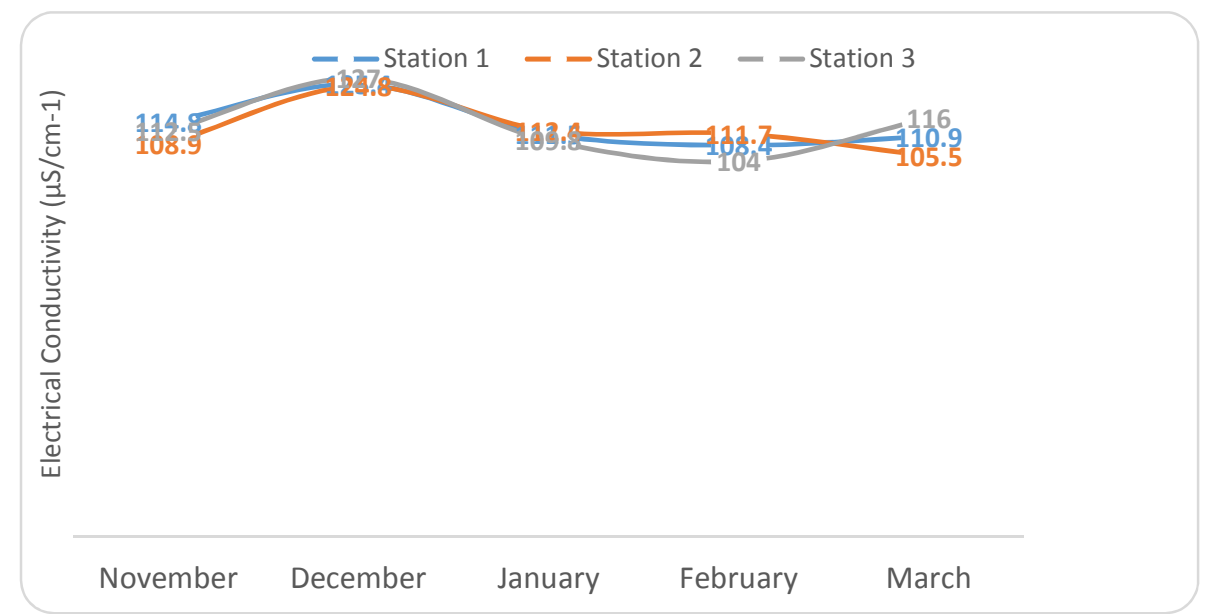

Fig. 13. Electrical conductivity variations among three sampling stations of River Hadejia

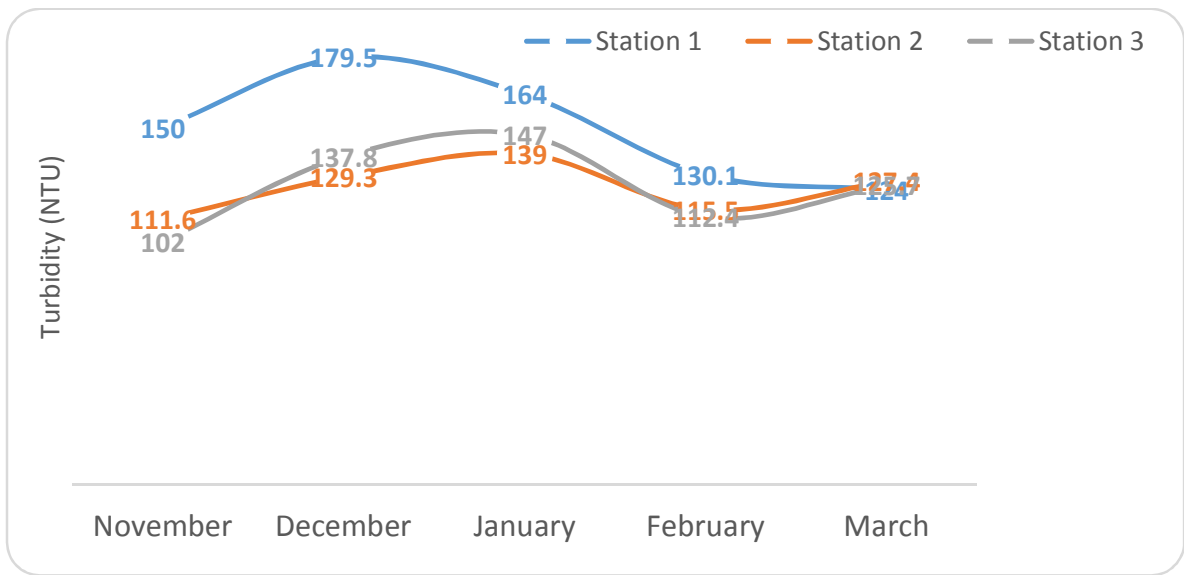

Fig. 14. Turbidity variations among three sampling stations of River Hadejia

\section{CONCLUSION}

The physico-chemical variables of River Hadejia varied significantly in time and space. The River Hadejia can be inferred to be polluted as indicated by high values of electrical conductivity, Turbidity and low values of and dissolved oxygen recorded in some of the stations sampled. With this, it is obvious that the level of anthropogenic activities around the River Hadejia and its tributaries has contributed to the change of physico-chemical variables and thus could led to disabling the efficiency and utilization of river water for domestic purpose.

\section{COMPETING INTERESTS}

Authors have declared that no competing interests exist.

\section{REFERENCES}

1. Edegbene AO, Arimoro FO, Odume ON. Developing and applying a macroinvertebrate-based multimetric index for urban rivers in the Niger Delta, Nigeria, Ecol. Evol. 2019;1-17.

2. Arimoro FO, Ikomi RB, Iwegbue CMA. Ecology and abundance of oligochaetes as indicators of organic pollution in an Urban Stream in Southern Nigeria. Pakistan J. Biol. Sci. 2007;10(3):446-453.

3. Griffin NJ, Palmer CG, Scherman PA. Critical Analysis of environmental water quality in South Africa: Historic and current trends report to the Water Research Commission, no. 2184; 2014.

4. Water Quality Management. Australian and New Zealand Guidelines for fresh and 
marine water quality, Natl. Water Qual. Manag. Strateg; 2000.

5. Umar DA, Ramli MF, Aris AZ, Jamil N, Tukur Al. Surface water resources management along Hadejia River Basin, northwestern Nigeria. $\mathrm{H}_{2}$ Open J. 2019; 2(1):184-199.

6. Talling JF. $\mathrm{pH}$, the $\mathrm{CO}_{2}$ System and Freshwater Science. Freshw. Rev. 2010; 3(2):133-146.

7. Bisi-Johnson MA, Adediran KO, Akinola SA, Popoola EO, Okoh Al. Comparative physicochemical and microbiological qualities of source and stored householdwaters in some selected communities in southwestern Nigeria. Sustain. 2017;9(3):1-11.

8. Stone $\mathrm{N}$, Shelton JL, Haggard BE, Thomforde HK. Interpretation of water analysis reports for fish culture. South. Reg. Aquac. Cent; 2013.

9. Fatoki OS, Gogwana P, Ogunfowokan AO. Pollution assessment in the Keiskamma River and in the impoundment downstream. Water SA. 2003;29(2):183187.

10. Muhammad MD, MMA, Idi BY, Gambo J, Yunusa $H Z$, Ahmad $G$, Idris AM. Assessment of ground water quality using geiger muller counter in Kafin Hausa Jigawa State, Nigeria. Semi-Arid J. Acad. Res. Dev. 2019;2(2):74-82.

11. Islam MM, Karim MR, Zheng $X$, Li X. Heavy metal and metalloid pollution of soil, water and foods in Bangladesh: A critical review. International Journal of Environmental Research and Public Health; 2018.

12. TV R. Spatial analysis and characterisation of lentic ecosystems: A Case Study of Varthur Lake, Bangalore. Int. J. Ecol. Dev; 2008.

13. AE, NV Ogueri C. Assessment of heavy metals in fish species and some physicochemical parameters of Oguta lake, Oguta, Imo state, Nigeria. Int. J. Hydrol. 2018;2(2): 116-119.

14. Ejieji C, Amodu M, Adeogun A. Prediction of the streamflow of Hadejia-Jama'areKomadugu-Yobe-River Basin, North Eastern Nigeria, using swat model. Ethiop. J. Environ. Stud. Manag. 2016;9(2):209.

15. Yilmaz N. Assesment of seasonal variation of phytoplankton and related water quality parameters of Sazlidere Dam Lake (Istanbul, Turkey). Desalin. Water Treat; 2018.
16. Ag Y, Imk G, Sj O, Mm B. Temporal and spatial variations in physico-chemical parameters of a small urban stream, Kaduna, Nigeria. Int. J. Fish. Aquat. Stud. 2017;5(3):593-599.

17. Damo R, Icka P. Evaluation of water quality index for drinking water. Polish $\mathrm{J}$. Environ. Stud; 2013.

18. Khaledian $Y$, Ebrahimi S, Natesan U, Basatnia N. Urban Ecology, Water Quality and Climate Change; 2018.

19. Idris $M$, Kolo $B$, Garba $S$, Ismail $M$. Physico-chemical analysis of pharmaceutical effluent and surface water of River Gorax in Minna, Niger State, Nigeria. Bull. Environ. Pharmacol. Life Sci.; 2013.

20. Sonia Sethi AP. Analysis of water quality using physicochemical and icrobiological parameters in verjeshwari reservoir of Mumbai, India. Int. J. Appl. Nat. Sci; 2016.

21. Mahmood R, Jia S. Analysis of causes of decreasing inflow to the Lake Chad due to climate variability and human activities. Hydrol. Earth Syst. Sci. Discuss; 2018.

22. Gambo J, Ayusuf Y, Ahmed G, Garba SA, Idris AM, Abdulkarim K. Causes and health effects of water pollution in domestic water sources in Hadeija Metropolis, Nigeria, using Statistical Modeling. Niger. Res. J. Chem. Sci. 2018;4.

23. Thomas DHL, Adams WM. Adapting to Dams: Agrarian change downstream of the Tiga Dam, Northern Nigeria. World Dev; 1999.

24. Olofin EA. Some effects of the Tiga Dam on valleyside erosion in downstream reaches of the River Kano. Appl. Geogr; 1984.

25. Apha WEF. AWWA, 1995. Standard methods for the examination of water and wastewater. Amer. Pub. Heal. Assoc. Washingt. DC; 1998.

26. Hammer $\varnothing$, Harper DAT, Ryan PD. Past: Paleontological statistics software package for education and data analysis. Palaeontol. Electron; 2001.

27. Edokpayi CA, Lawal MO, Okwok NA, Ogunwenmo CA. Physico-chemical and macrobenthic faunal characteristics of Kuramo Water, Lagos, southern Nigeria. African J. Aquat. Sci; 2004.

28. Oluyemi EA, Adekunle AS, Adenuga AA, Makinde WO. 71334-154027-1-Pb. 2010;4: 691-697. 
29. Arimoro FO, Muller WJ. Mayfly (Insecta: Ephemeroptera) community structure as an indicator of the ecological status of a stream in the Niger Delta area of Nigeria. Environ. Monit. Assess. 2010;166(14): 581-594.

30. Rueda J, Camacho A, Mezquita F, Hernández R, Roca JR. Effect of episodic and regular sewage discharges on the water chemistry and macroinvertebrate fauna of a Mediterranean stream. Water. Air. Soil Pollut; 2002.

31. Beyene A, Legesse W, Triest L, Kloos H. Urban impact on ecological integrity of nearby rivers in developing countries: The Borkena River in highland Ethiopia. Environ. Monit. Assess. 2009;153(14): 461-476.

(c) 2020 Adam et al.; This is an Open Access article distributed under the terms of the Creative Commons Attribution License (http://creativecommons.org/licenses/by/4.0), which permits unrestricted use, distribution, and reproduction in any medium, provided the original work is properly cited.

Peer-review history:

The peer review history for this paper can be accessed here: http://www.sdiarticle4.com/review-history/54512 